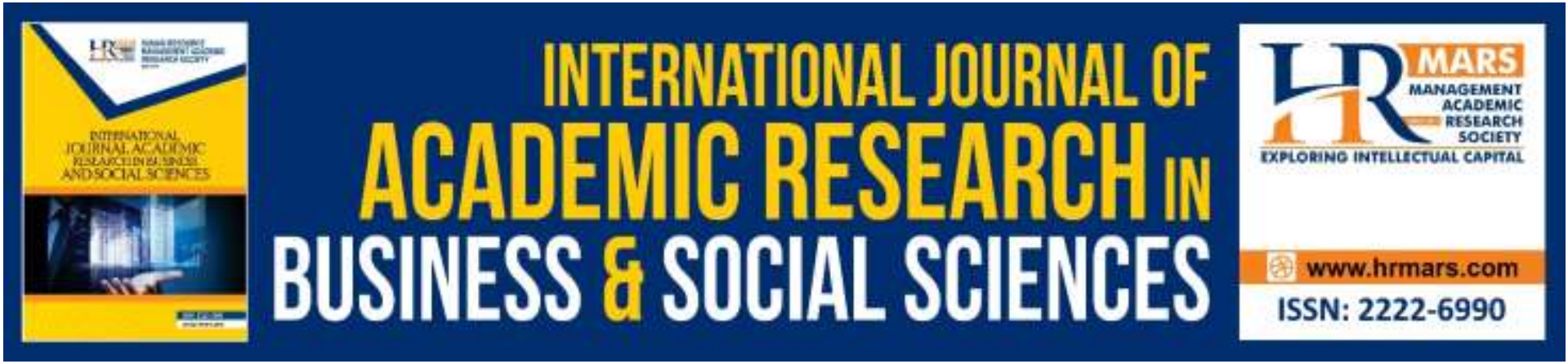

\title{
The Validity and Reliability of Instrument on Memorizing Al-Quran Strategy using Rasch Model
}

\author{
Noor Fadilah Ambo and Siti Eshah Mokhsein
}

To Link this Article: http://dx.doi.org/10.6007/IJARBSS/v9-i9/6412

DOI: $10.6007 /$ IJARBSS/v9-i9/6412

Received: 17 July 2019, Revised: 11 August 2019, Accepted: 29 August 2019

Published Online: 25 September 2019

In-Text Citation: (Ambo \& Mokhsein, 2019)

To Cite this Article: Ambo, N. F., \& Mokhsein, S. E. (2019). The Validity and Reliability of Instrument on Memorizing Al-Quran Strategy using Rasch Model. International Journal of Academic Research in Business and Social Sciences, 9(9), 1176-1183.

\section{Copyright: (C) 2019 The Author(s)}

Published by Human Resource Management Academic Research Society (www.hrmars.com)

This article is published under the Creative Commons Attribution (CC BY 4.0) license. Anyone may reproduce, distribute, translate and create derivative works of this article (for both commercial and non-commercial purposes), subject to full attribution to the original publication and authors. The full terms of this license may be seen

at: http://creativecommons.org/licences/by/4.0/legalcode

Vol. 9, No. 9, 2019, Pg. 1176 - 1183

Full Terms \& Conditions of access and use can be found at http://hrmars.com/index.php/pages/detail/publication-ethics 


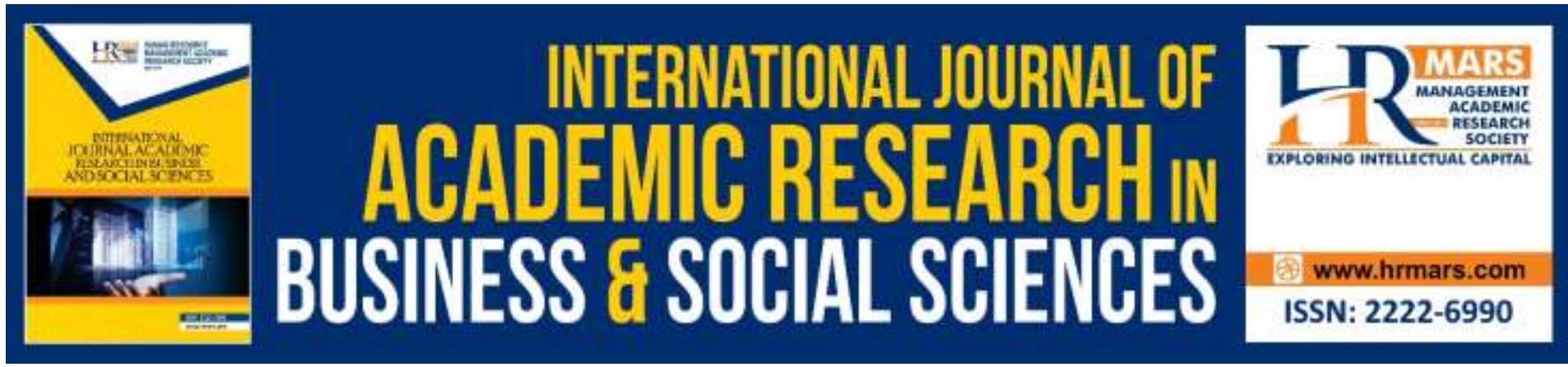

\title{
The Validity and Reliability of Instrument on Memorizing Al-Quran Strategy using Rasch Model
}

\author{
Noor Fadilah Ambo ${ }^{1}$ and Siti Eshah Mokhsein ${ }^{2}$ \\ ${ }^{1}$ MRSM Kota Kinabalu, P.O.Box 50167, 88722 Putatan, Kota Kinabalu, Sabah, Malaysia, \\ ${ }^{2}$ Faculty of Human Development, Universiti Pendidikan Sultan Idris, \\ 35900 Tanjung Malim, Perak, Malaysia
}

\begin{abstract}
This study was conducted to test the validity and reliability of Strategical Instrument on Memorizing al-Quran (ISMEQ) using Rasch Measurement Model that was aided with the Winstep 3.72 software. This instrument contains 54 items that consist of four construct and 10 sub-construct. The first construct was the objective strategy with two sub-construct which were the ability to memorize with a given timeline and the ability to memorize by per page a day. Meanwhile, the second construct was planning strategy with a sub-construct that consist of prior, during and after memorizing planning. The third construct was memorizing enforcement activity with two sub-construct which were preservation of hafazan and practice. Then, the fourth construct was effective strategy with four sub-construct which consist of internal and external motivational, interest and behavior. This study was conducted on 31 SMA Imtiyaz Besut students and 55 students from SMKA Kota Kinabalu. The result from this study show that the reliability of the respondents was .89 and the reliability for item .96 was in likert scale. The result also had shown that there were two misfit items. These items can be either be dismissed or improved in order to make the instrument fair and more reliable towards the respondent.
\end{abstract}

Keywords: Memorizing Al-Quran Strategy, Rasch Model, Item Analysis, Validity, Reliability and Education.

\section{Introduction}

According to Mokhsein (2018), the Rasch Model was the earliest model that used Respon Item Theory (RIT) because of its main feature of probabilities that was designed to answer main questions which were; when an individual with certain ability (number of test items correct) face with an item with certain difficulty parameter (the number of candidates who answered the item correctly), what is the likelihood that the individual can answer the item correctly? (Bon and Fox, 2012). With Rasch model, these probabilities will be increasing, parallel with the amount of other item parameter such as difficulty parameter, discrimination parameter and difficulty parameter. 
Hence, it was found that with only using Rasch measurement model, problems such as producing linear measurement, ability to use all kind of data, tracing misfit or outliner and giving separate instrument measurement or not relying on object parameter that was absorbed can be solved (Aziz, Zaharim, 2017; Sangakala, Ahmed, \& Pahi, 2016); Matarid, Sobh, \& Ahmed, 2018). Not only that, Rasch model are also able to identify the inaccuracy of model and produce repeatable measurement. Thus the objective of this study are for:

1. Testing the validity of Strategical Instrument on Memorizing al-Quran (ISMEQ) construct from the perspective of
a. Unidemensionality
b. Suitability and Correspondence item (fit)
c. Item Polarity

2. Measuring the reliability of of Strategical Instrument on Memorizing al-Quran (ISMEQ)

\section{Methodology}

This study was conducted using quantitative method due to its ability to collect and analyse data in numerical from for the purpose of explaining the research

\section{Sample and Data Collection}

A total of 86 Tahfiz students under the Ulul Albab Model representing from Sekolah Menengah (SM) Imtiyaz and Sekolah Menengah Kebangsaan Agama (SMKA). Based on Table 1.0, the amount of sample was sufficient to determine a stable benchmark, (Linacre, 1994).

Table 1. Measurement of Sample Size in Rasch Measurement Model

\begin{tabular}{|l|c|c|c|}
\hline \multicolumn{1}{|c|}{$\begin{array}{c}\text { Stable internal item } \\
\text { calibration }\end{array}$} & $\begin{array}{c}\text { Confidence } \\
\text { level }\end{array}$ & $\begin{array}{c}\text { Average } \\
\text { minimum sample } \\
\text { Size }\end{array}$ & $\begin{array}{c}\text { Suitable sample } \\
\text { size }\end{array}$ \\
\hline \pm 1 logits & $95 \%$ & $16-36$ & 30 \\
\hline \pm 1 logits & $99 \%$ & $27-61$ & 50 \\
\hline \pm 0.5 logits & $95 \%$ & $64-144$ & 100 \\
\hline \pm 0.5 logits & $95 \%$ & $108-243$ & 150 \\
\hline
\end{tabular}

Linacre 1994

\section{Instrumentation}

This instrument was a modification from Malley \& Chamo' (1990) and Duncan \& McKeachie (2005) Languange Learning Strategy Model which was to know the students' learning strategy in memorizing the al-Quran. Table 2 shows that there are five parts in this instrument which is Part A Objective Strategy (6 item), Part B Planning Strategy (13 tem), Part C Strengthening Activity Strategy (18 item), Part D Affective Strategy (17 item) and Part E Demografical Information such as gender, school categories, completing the al-Quran, number of memorized juzu' and religious school background. 
Table 2. Contents of Classroom Assessment Literacy Measurement Scale

\begin{tabular}{|c|l|c|c|}
\hline Bil & Construct & Item ID & Measurement Scale \\
\hline 1 & Objective Strategy & A1A - A2C & 4-point Likert Scale \\
\hline 2 & Planning Strategy & B1A - B3C & 4-point Likert Scale \\
\hline 3 & Strengthening Activity Strategy & C1A - C3F & 4-point Likert Scale \\
\hline 4 & Affective Strategy & D1A - D3E & 4-point Likert Scale \\
\hline
\end{tabular}

\section{Data Analysis}

All of the data collected from the instrument are analyse through Rasch Measurement Model using Winstep Version 3.72 software following the prescribed procedure in Table 3.

Table 3. Analysing Data Procedure

\begin{tabular}{|c|c|c|}
\hline Aspect & Analysis purposes & Analysis procedure \\
\hline $\begin{array}{l}\text { Determination } \\
\text { instrument validity }\end{array}$ & Construct validity & $\begin{array}{l}\text { 1. Unidimensionality } \\
\text { 2. Local freedom } \\
\text { 3. Item polarity } \\
\text { 4. Item compatibility }\end{array}$ \\
\hline $\begin{array}{l}\text { Determination } \\
\text { instrument reliability }\end{array}$ & Realiability & $\begin{array}{l}\text { 1. Item reliability } \\
\text { 2. Individual reliability } \\
\text { 3. Item separation index } \\
\text { 4. Index of individual separation }\end{array}$ \\
\hline
\end{tabular}

\section{Findings}

This part will be reporting on the findings of this pioneer study in regards of the validity and reliability of Strategical Instrument of Memorizing al-Quran (ISMEQ).

Objective 1: To test the Strategical Instrument of Memorizing al-Quran (ISMEQ) from Rasch Model Measurement perspective based on
a. Unidemensionality
b. Suitability and Correspondence item (fit)
c. Item Polarity

\section{Unidemensionality}

Based on Table 4 unidemensionality result analysis shows that this study instrument consist of

standardized variance value of $85.7 \%$ exceeded Rasch's requirement which was 50.5 percent and the biggest secondary dimension in $1.38 \%$ of the first contrast which does not exceeds the limit as prescribed by the Rasch Measurement Model with the minimum 40\% achievement.

Meanwhile, Table 5 shows the result local freedom analysis. There are 2 item that obtain over 00.7 corelation value. This shows that the respondent sees the relevant item partner as the same subject and are confused. There are two approach that can be taken which either the sentence structure are neutralized in order to give clearer understanding or it can dismiss 
absolutely. However, the dismissal process of these item should be done with caution to make sure the validity of the content and construct are not tainted.

Table 4. Principle Component Analysis

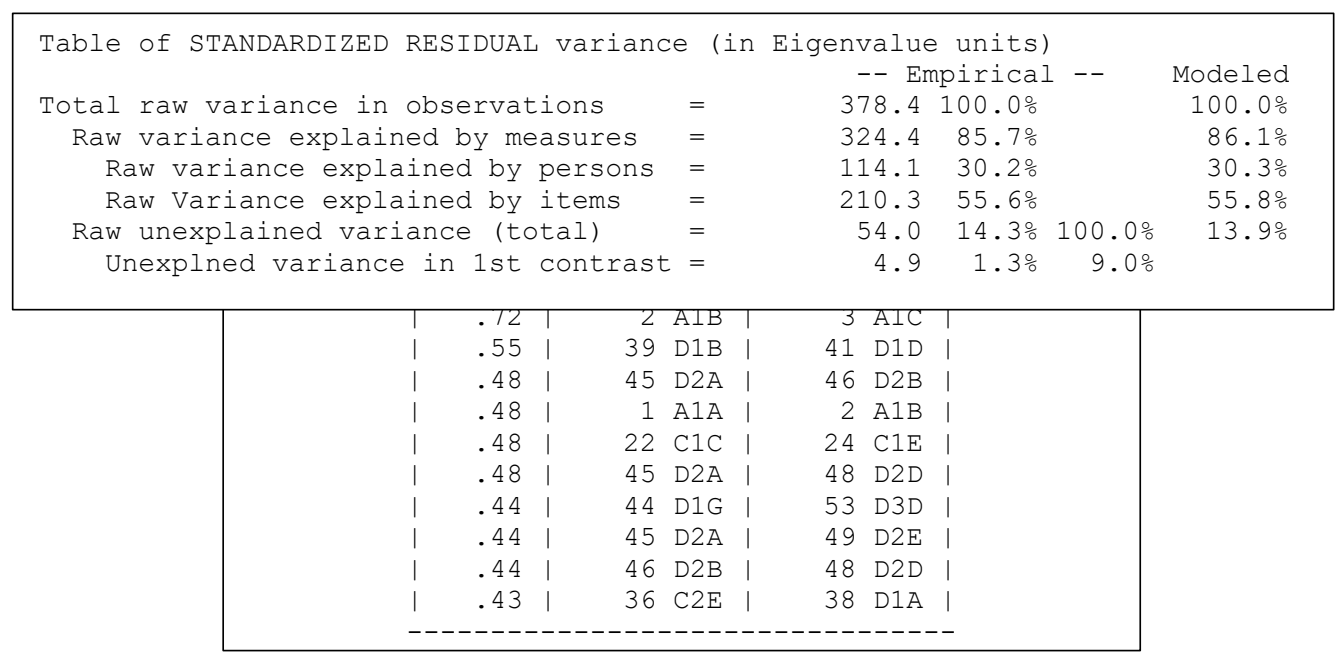

\section{Item Suitability or Correspondence/Misfit}

The item suitability item analysis shows that there are 52 items that obtain misfit value between 0.68 to 1.25. This value fulfils the given Bond \& Fox (2007) suitability average. There are two item which are (CIL) and (B2A) that exceed the prescribed suitability average. However these two items still need to be consider to be neutralized or dismissed by observing the researcher's need and expert opinion.

Table 6 shows infit/outfit MNSQ for 54 item ISMEQ. There are two items that reach infit/outfit MNSQ exceeding 1.40 logit which are C1L(1.30/2.19 logit) item and B2A(1.56/1.48 logit).

Table 6. Suitability Fit / item according to construct

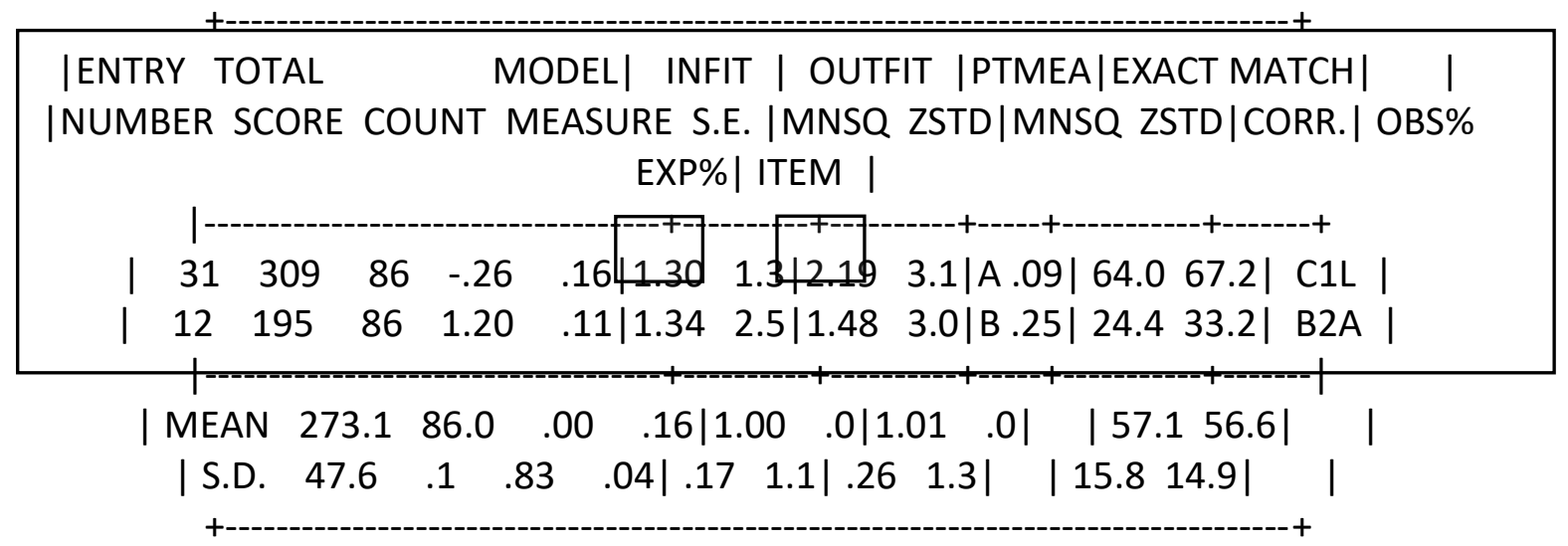

The higher the value of 1.4 item logit shows that the logit is non-homogenous with other items in on measurement scale, meanwhile less than 0.6 shows redundancy with other item. Thus, the items that needed to be given attention or dismissed are CIL and B2A.

The item suitability analysis shows that there are 52 item that contain misfit value between 0.73 to 1.38 . This value reaches the Bond \& Fox (2007) average measurement. 


\section{Item Polarity}

Based on the item polarity, the analysis shows all of the 54 ISMEQ item have positive PMC value between 0.33 to 0.77 . This proves that the measured item is in the same lane and does not contradict with the other construct that needed to be measured.

\section{Objective 2: Measuring the Reliability Strategical Instrument of Memorizing al-Quran (ISMEQ)}

Table 7 shows the individual reliability value is 0.89 and the separation individual index is 2.78 . This shows the individual reliability for all construct is uniform. This is because even though the set item given are different, but they still measure the same construct and the instruments item differentiate individuals to four separate categories of capability.

On the other hand, Table 8 shows each of its own reliability item value and separation index item with 0.96 and 4.68 respectively. This means these item instrument is sufficient to measure what that are supposed to be measured and the amount of individual sample are able to determine that there are 3 hierarchy of difficulty for this item instrument.

Table 7. Individual Reliability Index and Individual Separation Index Analysis

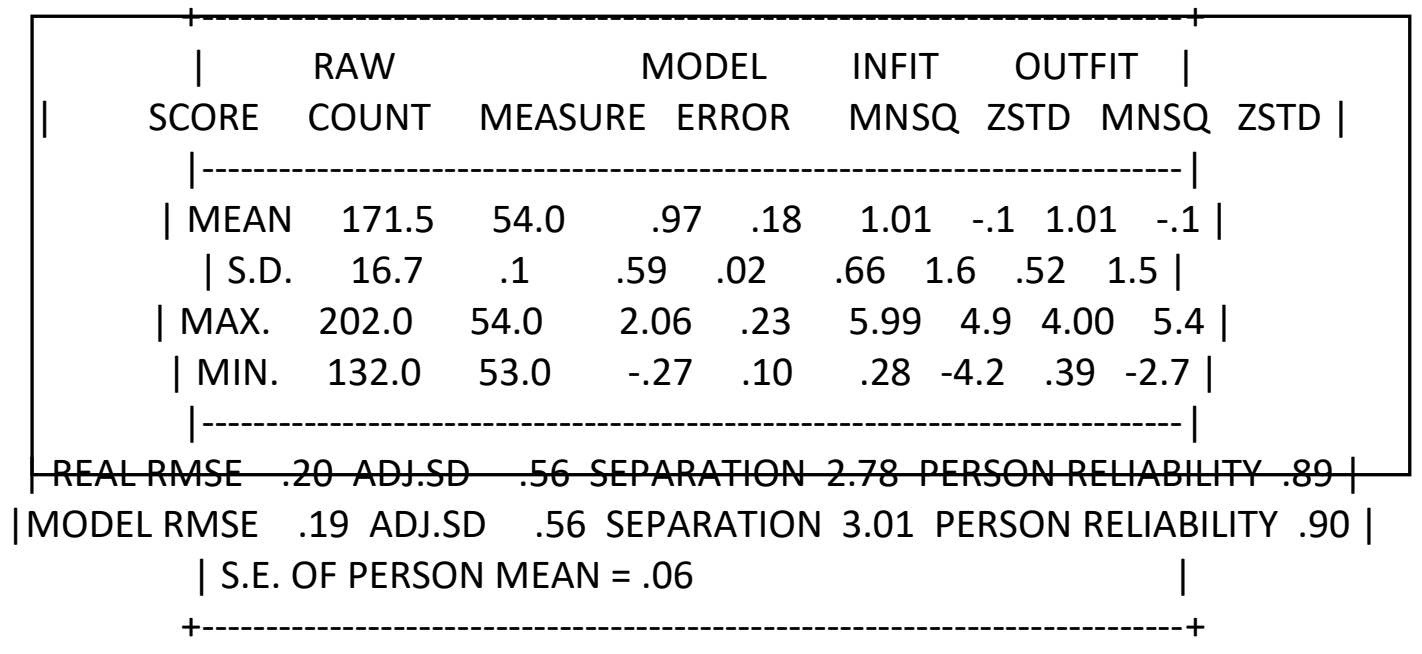

Table 8. Reliability Item Index and Separation Item Index Analysis

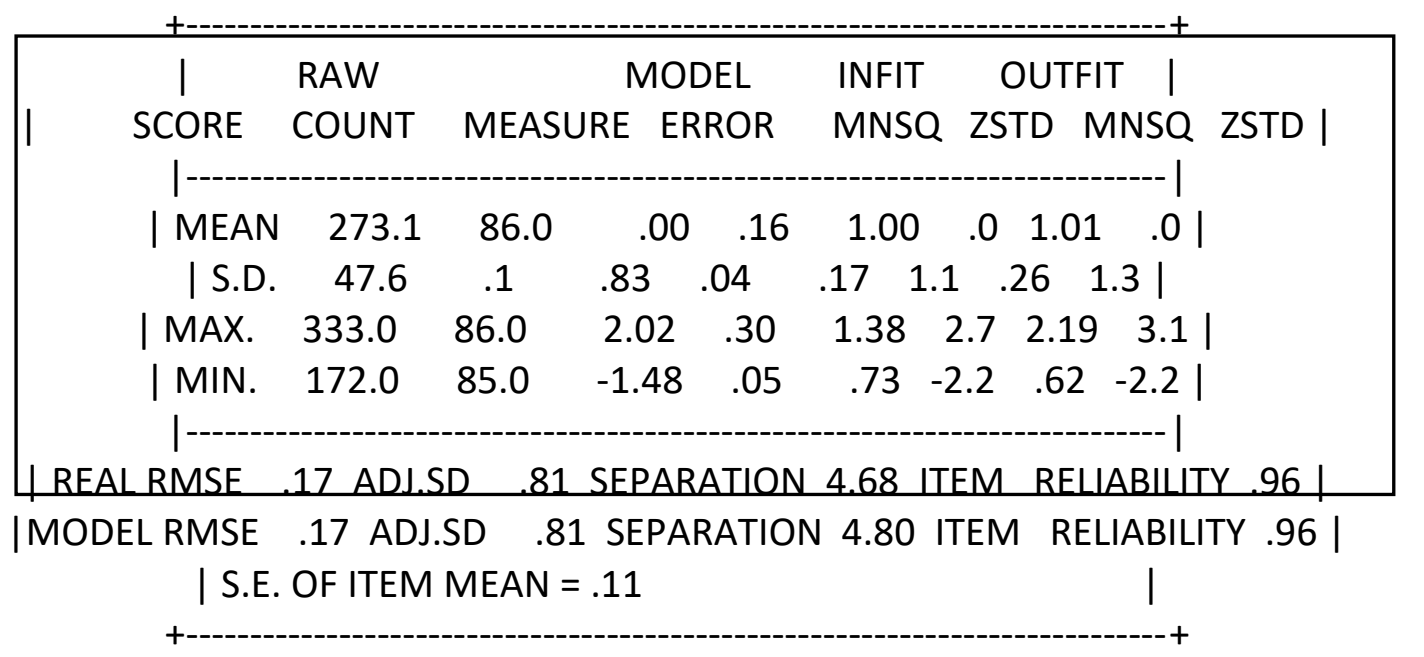




\section{Discussion and Summary}

In conclusion, after the data had been analysed it was proven that rechecking every item with following the index standard and their condition need to followed to achieve the validity and reliability standard instrument based on the Rasch Model. Based on the pioneer study that had been conducted, there were two items that does not follow the provided standard analysis and need to be removed or neutralized by considering specialist's evaluation and opinion. Meanwhile, the other 52 items have a high rate of validity and reliability to measure student's memorizing strategy. With that, this pioneer study can conclude that the validity and reliability test shows that the Strategical Instrument of Memorizing al-Quran (ISMEQ) have a quality that can be used to measure memorizing strategy in Malaysian context. The implication from this is that it can help researchers in developing memorizing strategy instrument that is at par with the standards of Tahfiz Ulul Albab Model (TMUA) in Malaysian context. This is also an early step in helping all parties involved in producing more huffaz alQuran.

\section{Corresponding Author}

Noor Fadilah Ambo

MRSM Kota Kinabalu

P.O.Box 50167

88722 Putatan

Kota Kinabalu, Sabah

Email: fadilahambo@gmail.com

\section{References}

Sangakala, M., Ahmed, U., \& Pahi, M. H. (2016). Empirical investigating on the role of supervisor support, job clarity, employee training and performance appraisal in addressing job satisfaction of nurses. International Business Management, 10(23), 5481-5486.

Matarid, N. M., Sobh, O. S., \& Ahmed, U. (2018). The Impact of Organizational Justice and Demographics on Faculty Retention in Bahrain. Le travail humain, (3).

Abdul, A., Saidfudin, M., and Azami Z. (2017). Asas Model Pengukuran Rasch:

Pembentukan Skala \& Struktur Pengukuran. Bangi: Universiti Kebangsaan

Malaysia. Bond, T. G., \& Fox, C. M. (2007). Applying the Rasch Model. Lawrence Erlbaum Associates, Inc., Publisher: New Jersey.

Bond, T. G., \& Fox, C. M. (2012). Applying the Rasch Model Fundamental Measurement in the HumanSciences. Edisi ke-2. New York: Routledge Taylor \& Francis Group.

Duncan., \& McKeachie. (2005) Duncan, T.G. and McKeachie. W.J. (2005) The Making of the Motivated Strategies for Learning Questionnaire. Educational Psychologist, 40, 117128.

Linacre, J. M. (2019). Winsteps ${ }^{\circledR}$ (Version 4.4.1) [Computer Software]. Beaverton, Oregon: Winsteps.com. Retrieved January 1, 2019. Available

from https://www.winsteps.com/

Linarce, J. M. (2005). Measurement, Meaning And Morality (Electronic Version). Rasch Research Papers, Explorations And Explanations: Research Papers And Memoranda. retrieved $5^{\text {th }} \quad$ March from http://www.rasch.org/memo71.pdf. 
O'Malley, J. Michael and Anna Uhl Chamot (1990). Learning Strategies in Second Language Acquisition. Cambridge: Cambridge University Press.

Eshah, S. M. (2018) Aplikasi Teori Respon Item dalam Penyelidikan. Perak: Universiti Pendidikan Sultan Idris. 